\title{
The Superimmunity Gene sim of Bacteriophage P1 Causes Superinfection Exclusion
}

\author{
MANFRED KLIEM AND BRIGITTE DREISEIKELMANN ${ }^{1}$ \\ Universität Bielefeld, Fakultät für Biologie, Lehrstuhl für Gentechnologie/Mikrobiologie, \\ Postfach 8640, 4800 Bielefeld, Federal Republic of Germany \\ Received February 3, 1989; accepted March 30, 1989
}

\begin{abstract}
Previous work has shown that the sim gene of bacteriophage $\mathrm{P} 1$, if cloned into a multicopy vector, confers immunity against $P 1$ infection to cells. We show that a 1.85-kb DNA fragment from the sim region of P1 (in the multicopy plasmid pMK4) expresses immunity and encodes three proteins with molecular weights of about 25, 24, and $15 \mathrm{kDa}$. Deletion of $650 \mathrm{bp}$ from the sim region abolished synthesis of all three proteins and of the sim phenotype. Expression of sim did not prevent adsorption of P1 to cells. Successful transfection with linear P1 DNA suggests that the recombinational circularization of P1 DNA is not inhibited in the presence of sim. Plasmid pMK4 and a P1 prophage can be stably maintained in the cell indicating that replication of the prophage is not disturbed by sim. The prophage can be induced in the presence of sim. This shows that the sim phenotype is not caused by preventing lytic replication or phage maturation. In cells with pMK4 there is no expression of genes from infecting phages and transduction frequency is drastically reduced. We suggest that sim functions as a superinfection exclusion system by preventing transfer of DNA from the adsorbed phages into the cytoplasm. (1989 Academic Press, Inc.
\end{abstract}

\section{INTRODUCTION}

The immunity system of bacteriophage $P 1$ consists of at least two independent regulatory circuits. The related genes are located in the regions $i \mathrm{mmC}$ and $i \mathrm{mml}$ (for review see Scott, 1980; Sternberg and Hoess, 1983). Within the $i m m C$ region there is the $c 1$ repressor gene and some of its regulating functions. The $\mathrm{c} 1$ repressor maintains the lysogenic state by repressing Iytic genes. Since P1 lysogens are not immune to the closely related phage $\mathrm{P} 7$ although the $c 1$ genes of both phages are interchangeable, it became clear that there must be a further immunity function. This function is provided by the $c 4$ repressor (Scott et al., 1978). The c4 gene is located within the $\mathrm{imml}$ region on the left of the gene(s) ant coding for an antirepressor. The $c 4$ repressor prevents the expression of the antirepressor and thereby sustains the maintenance of lysogeny. The $c 4$ repressor also determines the specificity of immunity by preventing expression of the antirepressor gene(s) of a superinfecting homologous phage.

The sim gene of bacteriophage $\mathrm{P} 1$ was detected during attempts to clone the $c 1$ gene (Devlin et al., 1982). After shotgun cloning, transformed cells were screened for the active repressor by testing for immunity to $\mathrm{P} 1$ infection. Surprisingly the immune clones contained two different kinds of plasmids. One kind of plasmid carried the $c 1$ gene as expected (ECoRI-7 fragment); the other kind carried the EcoRI-9 fragment of P1 (Bächi and Arber, 1977). When the EcoRI-9 frag-

\footnotetext{
${ }^{1}$ To whom requests for reprints should be addressed.
}

ment was inserted into a multicopy vector it did not only confer immunity to wild-type $\mathrm{P} 1$ phage but also to the mutants $c 1$ and $v i r^{s}$ and to the heteroimmune phage P7. On the basis of its phenotype the gene was termed $\operatorname{sim}$ (superimmunity). In a low copy number vector the sim gene did not express the superimmunity phenotype. Although closely linked, $c 4$ and sim are two separate genes transcribed from different promoters. Transposon mutagenesis led to the suggestion that the minimal size of the sim gene is about $1 \mathrm{~kb}$.

Several possible mechanisms for sim-mediated superimmunity have been discussed (Devlin et al., 1982). The phenotype could result from the overproduction of a structural phage protein which would prevent correct phage assembly. Another possibility is that $\operatorname{sim}$ could be a nontranscribed region on the genome which would titrate proteins engaged in replication. Finally the sim gene might code for a repressor regulating the switch from early to late functions during lytic development.

We have cloned a P1 DNA fragment expressing the sim phenotype on a multicopy plasmid. With this plasmid we have examined several possible ways in which the superimmunity could be exerted by the sim gene. The data led us to conclude that sim acts by a superinfection exclusion mechanism.

\section{MATERIALS AND METHODS}

\section{Bacterial strains \\ If not mentioned otherwise all experiments were per- formed with Escherichia coli $\mathrm{C} 600 \mathrm{~F}^{-}$, thi-1, leuB6,}


lacY1, supE44, tonA21. Minicells were isolated from $E$. coli DS4 10 minA, minB, Str', lacY, xyl, mtl, thi. $\mathrm{Ca}^{2+}$ cells for transfection of $\mathrm{P} 1$ DNA were prepared from WA236 recBC21, sbcB15, recC22, arg, his, pro, thr, leu, thi. The recipient strain for bacterial transduction was E. coli AB1 157 pro, leu, thr, arg, his, thi, ara, $x y$ l, $m t l$, lac, gal.

\section{Phage strains}

Phages P1Cmc1.100 (encudes a thermosensitive repressor), $\mathrm{P} 1 \mathrm{C} 4.32$, and $\mathrm{P} 1$ vir $^{\mathrm{s}}$ were from J. Scott via A. Pühler. Phage P7 was from W. Arber; Mu from R. Simon; T4, T5, and T7 from W. Rüger; and $\lambda$ and $\phi \times 174$ from R. Eichenlaub.

\section{Media}

Because phage $\mathrm{P} 1$ needs $\mathrm{Ca}^{2+}$ for adsorption most cultures were grown in RGMC medium: $10 \mathrm{~g}$ tryptone, $1 \mathrm{~g}$ yeast extract, $8 \mathrm{~g} \mathrm{NaCl}, 1 \mathrm{~g}$ glucose, $1 \mathrm{~g} \mathrm{MgCl}_{2}$, $0.5 \mathrm{~g} \mathrm{CaCl}_{2}$ per liter. Phage dilutions were performed in SM-Ca: $20 \mathrm{mM}$ Tris- $\mathrm{HCl}, \mathrm{pH} 7.5,10 \mathrm{mM} \mathrm{NaCl}, 5 \mathrm{mM}$ $\mathrm{MgCl}_{2}, 5 \mathrm{mMCaCl}$.

Transformation of $\mathrm{Ca}^{2+}$ cells was performed according to the method of Maniatis et al. (1982). Transfection of $\mathrm{Ca}^{2+}$ cells was performed as described previously (Mandel and Higa, 1970).

\section{Transduction of bacterial markers}

Phage $\mathrm{P} 1 \mathrm{Cmc} 1.100$ was grown in E. coli $\mathrm{C} 600$ and the lysate was diluted to a titer of $5 \times 10 \% \mathrm{ml}$. An overnight culture of $E$. coli $\mathrm{AB} 1157$ was washed twice in SM-Ca and diluted to a titer of $5 \times 10^{8} / \mathrm{ml}$. To $1.8-\mathrm{ml}$ aliquots of cells, $0.2 \mathrm{ml}$ of phage-lysate was added. Preadsorption was performed at $37^{\circ}$ for 20 min without shaking. Samples were plated on appropriately supplemented $\mathrm{M} 9$ plates and incubated for $48 \mathrm{hr}$ at $37^{\circ}$.

Isolation of minicells from E. coli DS410 was performed as previously described (Magazin et al., 1978; Reeve, 1979).

\section{Radioactive labeling of plasmid-encoded proteins in minicells}

Five hundred microliters of minicells $\left(1 \times 10^{10}\right.$ cells $)$ was mixed with $150 \mu \mathrm{l}$ methionine assay medium (Difco) and $10 \mu \mathrm{Ci}\left[{ }^{35} \mathrm{~S}\right.$ ]methionine (Amersham, sp act $1350 \mu \mathrm{Ci} / \mathrm{mmol}$ ) and incubated at room temperature for $1 \mathrm{hr}$. After centrifugation cells were lysed and prepared for SDS-PAGE.

\section{SDS-PAGE}

Polyacrylamide slab gels (14-20\%, 1-mm thick, 20$\mathrm{cm}$ long) were prepared according to the method of
Laemmli (1970). Electrophoresis was performed for 16 hr at $130 \mathrm{~V}, 20 \mathrm{~mA}$. Gels were dried, treated with Amplify (Amersham), and autoradiographed on Cronex 2 $X$-ray films (DuPont). A molecular-weight-marker mix of ${ }^{14} \mathrm{C}$-methylated proteins was from Amersham: myosin (mol wt 200,000), phosphorylase B (mol wt 97,400), bovine serum albumin (mol wt 68,000), chymotrypsinogen (mol wt 25,700), $\beta$-lactoglobulin (mol wt 18,400), lysozyme (mol wt 14,300).

\section{RESULTS}

\section{Identification of proteins required for the sim phenotype}

The multicopy plasmid pMK4 consists of the vector pUC13 (Vieira and Messing, 1982) and a 1.85-kb NrulPvull DNA fragment of the ECoRI-9 of P1 DNA (Fig. 1). This plasmid expresses the superimmunity phenotype but does not carry the $c 4$ gene excluding any interference of $c 4$ activity with immunity (Baumstark and Scott, 1987).

Before looking for a sim gene product, it was necessary to limit the insert of plasmid pMK4 to the region essential for expression of superimmunity. Therefore deletion derivatives of plasmid pMK4 were produced by the method of Yanisch-Perron et al. (1985). Plasmid pMK4 was digested with the restriction endonucleases $\mathrm{BamHI}$ and Sacl. The linearized molecules, with one protruding $5^{\prime}$ end at the insert site and a $3^{\prime}$ protruding end at the vector site, were partially degraded by exonuclease III followed by exonuclease VII. After religation a population of plasmids was obtained with various deletions extending from the Nrul site of the P1 DNA insert. The size of deletion was determined and the expression of immunity was tested (Fig. 1). Plasmids with deletions up to $550 \mathrm{bp}$ from the Nrul site (pMK4d6) still conferred immunity to the cell. Deletions of $650 \mathrm{bp}$ and larger resulted in a loss of the immunity phenotype (pMK4d7). These results are in agreement with data of Devlin et al. (1982) who used transposon mutagenesis to show that one end of the sim gene was located at approximately $560 \mathrm{bp}$ from the Nrul site.

The synthesis of plasmid-encoded proteins in minicells was used to identify the gene product of sim. With plasmid pMK4 in minicells of $E$. coli DS410 we detected three protein bands on the autoradiogram in addition to the two major proteins ( $\beta$-lactamase) encoded by the vector. The three proteins have molecular weights of about 25,24 , and $15 \mathrm{kDa}$. These proteins are not expressed by the deletion derivatives pMK $4 \mathrm{~d} 7$ and pMK4d8. There are also two minor signals in the position of a 24-kDa protein and a 14.5-kDa protein with only vector pUC13. To verify that the $24-\mathrm{kDa}$ protein is also sim specific and not a result of an overpro- 


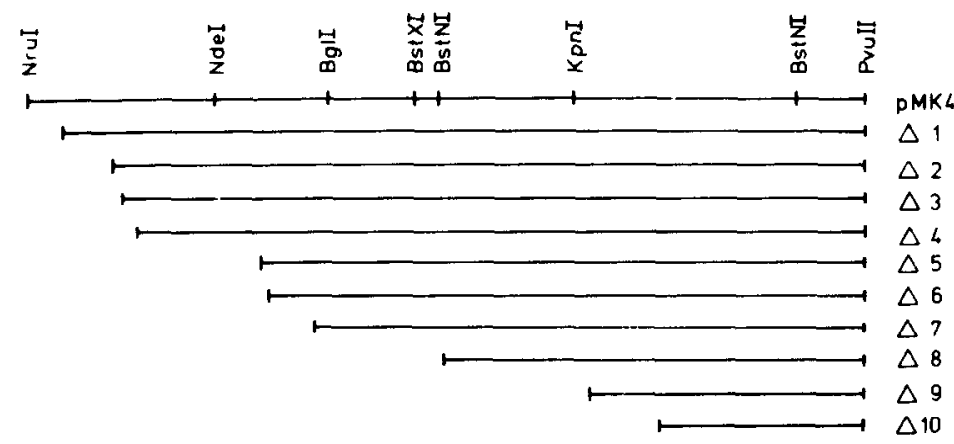

\begin{tabular}{|c|c|c|}
\hline$\underset{\substack{\text { ineort size } \\
\text { (bp) }}}{A}$ & $\underset{\substack{\text { immunity } \\
\text { (cross atroak) }}}{B}$ & $\underset{\text {..0.p }}{C}$ \\
\hline 1850 & + & $<5 \times 10^{-0}$ \\
\hline 1770 & + & $-5 \times 10^{-4}$ \\
\hline 1650 & + & $<5 \times 10^{-8}$ \\
\hline 1630 & + & $<5 \times 10^{-8}$ \\
\hline $\begin{array}{l}1600 \\
1320\end{array}$ & + & $\begin{array}{l}<5 \times 10^{-8} \\
<5 \times 10^{-8}\end{array}$ \\
\hline 1300 & + & $5 \times 10^{-8}$ \\
\hline 1200 & - & 0.8 \\
\hline 920 & - & 1.2 \\
\hline 600 & - & 1.1 \\
\hline 450 & - & 0.9 \\
\hline
\end{tabular}

FIG. 1. Deletion derivatives of plasmid pMK4 and their phenotype. (A) The insert size was determined from the mobility of DNA fragments during electrophoresis on a $1 \%$ agarose gel. $\lambda$ DNA digested with EcoRI and Hindlll was used as the molecular weight marker. (B) Single colonies from plates incubated overnight were cross-streaked against $\mathrm{P} 1 \mathrm{Cmc} 1.100\left(5 \times 10^{10} / \mathrm{ml}\right)$ on a RGMC plate and incubated overnight at $40^{\circ}$. + . growth of bacteria across the phage streak (immunity); - no growth across the phage streak (no immunity). (C) Dilutions (10 $\mu$ l) of a P1Cme 1.100 lysate were spotted on RGMC plates with $0.2 \mathrm{ml}$ overnight culture and $3 \mathrm{ml}$ soft agar and incubated overnight at $40^{\circ}$. The e.o.p. of 1 was determined with $E$. coli $\mathrm{C} 600$ containing the vector pUC 13 and corresponds to a titer of $5 \times 10^{10} / \mathrm{ml}$.

duction of a vector-encoded protein, the insert of pMK4 was also introduced into both the $\mathrm{Cm}$ and the Tc resistance genes of vector PACYC184. Figure 3 shows that

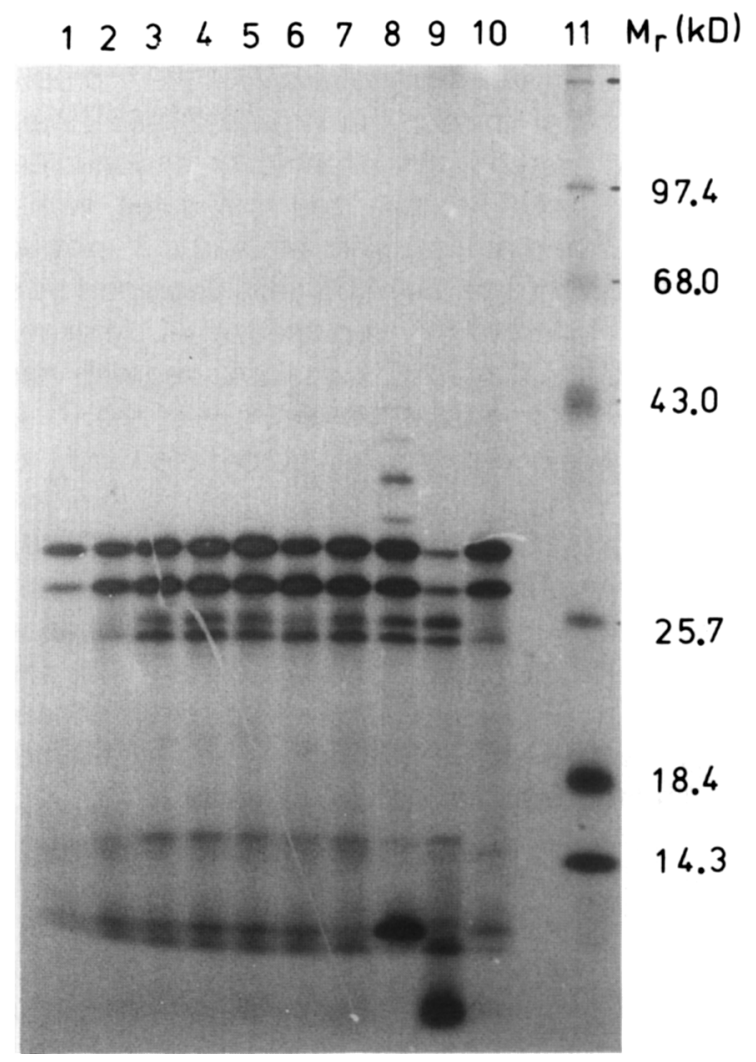

FIG. 2. Expression of genes from plasmid pMK4 and its deletion derivatives in minicells. The autoradiogram of a 14-20\% SDS-polyacrylamide gel shows the proteins synthesized in cells with the following plasmids $(1-10): 1$, pMK4d8; 2, pMK4d7; 3, pMK4d6; 4, pMK4d5; 5, pMK4d4; 6, pMK4d3; 7, pMK4d2; 8, pMK4d1; 9, pMK4; 10, pUC13; and 11, marker proteins. The two largest proteins expressed from all plasmids are the $\beta$-lactamase proteins. cells carrying the vector pACYC184 did not express the $24-\mathrm{kDa}$ protein and the $14.5-\mathrm{kDa}$ protein, but after insertion of the $1.85-\mathrm{kb}$ fragment the three proteins were observed. They were not expressed from deletion derivatives of pMK4 which had lost the sim phenotype indicating that superimmunity must be related to at least one of the proteins. The disappearance of all three proteins upon removal of about 100 nucleotides
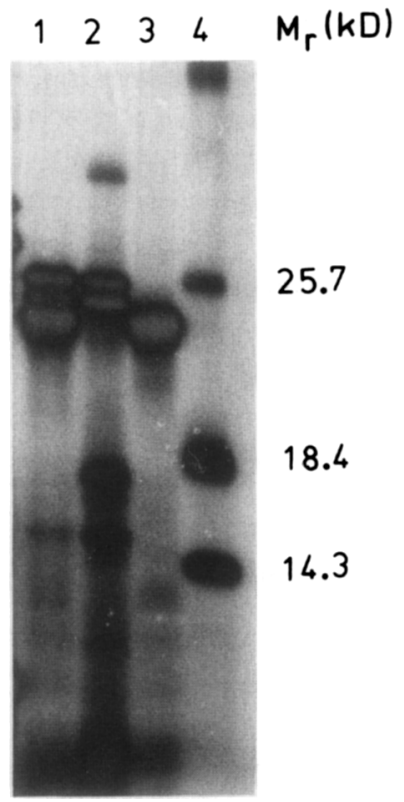

Fig. 3. Expression of the sim gene(s) after insertion into vector pACYC 184. Autoradiogram of $\left[{ }^{35} \mathrm{~S}\right]$ methionine-labeled proteins from cells with plasmid: (1) pMK5 = pACYC 184 with a 1.85-kb Nrul-Pvull P1 DNA fragment in the Hincll site of the Tc gene; (2) pMK6 $=\mathrm{pACYC} 184$ with a $3.5-\mathrm{kb}$ ECoRI fragment of P1 DNA in the ECoRI site of the $\mathrm{Cm}$ gene; (3) pACYC184. (4) Marker proteins. Proteins were separated by electrophoresis through a $14-20 \%$ SDS-polyacrylamide gel. 
TABLE 1

EFFECT OF SIM ON THE LYSOGENIZATION OF CELLS AFTER INFECTION WITH PHAGE P1Cmc1.100

\begin{tabular}{lccc}
\hline \multicolumn{1}{c}{ Strain } & Infection & Survivors/ml & Lysogens/ml \\
\hline C600 & - & $6 \times 10^{8}$ & $<10^{2}$ \\
C600 & + & $1 \times 10^{4}$ & $<10^{2}$ \\
C600 pMK4 & - & $8 \times 10^{8}$ & $<10^{2}$ \\
C600 pMK4 & + & $7 \times 10^{8}$ & $1 \times 10^{2}$ \\
C600 pBD1 & - & $8 \times 10^{8}$ & $<10^{2}$ \\
C600 pBD1 & + & $6 \times 10^{8}$ & $6 \times 10^{8}$ \\
C600 pBD1 pMK6 & - & $6 \times 10^{8}$ & $<10^{2}$ \\
C600 pBD1 pMK6 & + & $5 \times 10^{8}$ & $<10^{2}$ \\
\hline
\end{tabular}

Note. Log cells $\left(2 \times 10^{8} / \mathrm{mil}\right)$ of Escherichia coli $\mathrm{C} 600$ with or without plasmid were infected with $\mathrm{P} 1 \mathrm{Cmc} 1.100$ (m.o.i. about 5) and incubated for $1 \mathrm{hr}$ at $42^{\circ}$. Appropriate dilutions were plated parallel on RGMC plates and RGMC plates with $50 \mu \mathrm{g} / \mathrm{ml} \mathrm{Cm}$ and incubated overnight at $40^{\circ}$. Plasmid pBD1 which confers immunity to the cells by expression of the $c 1$ repressor gene served for comparison. Plasmid pMK6 is described in the legend to Fig. 2.

from the insert of pMK4d6 and the absence of a truncated protein in cells with pMK4d7 and pMK4d8 suggest that the deletions cover the promoter of the sim gene(s) and that all three proteins originate from a common mRNA.

\section{Infection of cells with pMK4 by phage $\mathrm{P} 1$}

With the following experiments we tried to find out which step during the development of phage $\mathrm{P} 1$ is blocked by the action of sim.

The adsorption of phage $\mathrm{P} 1$ to cells with pMK 4 was first tested. Growing cells were infected with phage P1 at a multiplicity of 1 , and after preadsorption for $15 \mathrm{~min}$ at $37^{\circ}$, cells were removed by centrifugation and phages in the supernatant were quantitated. Adsorption of phage P1 to cells with and without pMK4 was about $97 \%$. Thus sim seems not to prevent adsorption of phage P1. To test whether the sim protein acts as a "c1-like" repressor, cells with pMK4 were infected with phage P1Cmc1.100 and surviving and lysogenized fractions were determined on plates without and with chloramphenicol. For comparison cells overproducing the $c 1$ repressor from plasmid pBD1 (Dreiseikelmann et al., 1988) were also infected with $\mathrm{P} 1 \mathrm{Cmc1.100}$. The result is shown in Table 1. Cells expressing the $c 1$ repressor are not killed because they are lysogenized. Cells expressing the sim gene product also escape killing, but in contrast do not carry a prophage. Cells harboring two plasmids, one expressing $c 1$ (pBD1) and the other expressing sim (pMK5), again were not lysogenized after infection. From this observation we conclude that (i) the $c 1$ repressor does not regulate sim expression and (ii) that sim acts at an earlier stage of $P 1$ infection than the $c 1$ repressor.

In another experiment P1Cmc1.100 lysogenic cells were transformed with plasmid pMK4. The transformation efficiency was normal (about $8 \times 10^{3}$ clones $/ \mu \mathrm{g}$ DNA). Both prophage and plasmid pMK4 were stably maintained in the cells. This means that replication of the prophage is not hindered by the presence of a plasmid expressing sim.

After thermoinduction of P1c1.100 lysogenic cells carrying plasmid pMK4, normal lysis was observed and the titer of the lysate was nearly the same as of lysogens without $\mathrm{pMK} 4$. This shows that neither prophage maintenance or replication nor lytic replication or maturation of progeny phages is inhibited by sim function. The recombinational circularization of P1 DNA following the infection is an essential step for replication (Segev and Cohen, 1981; Sternberg et al., 1981). It could be possible that sim prevents this circularization,

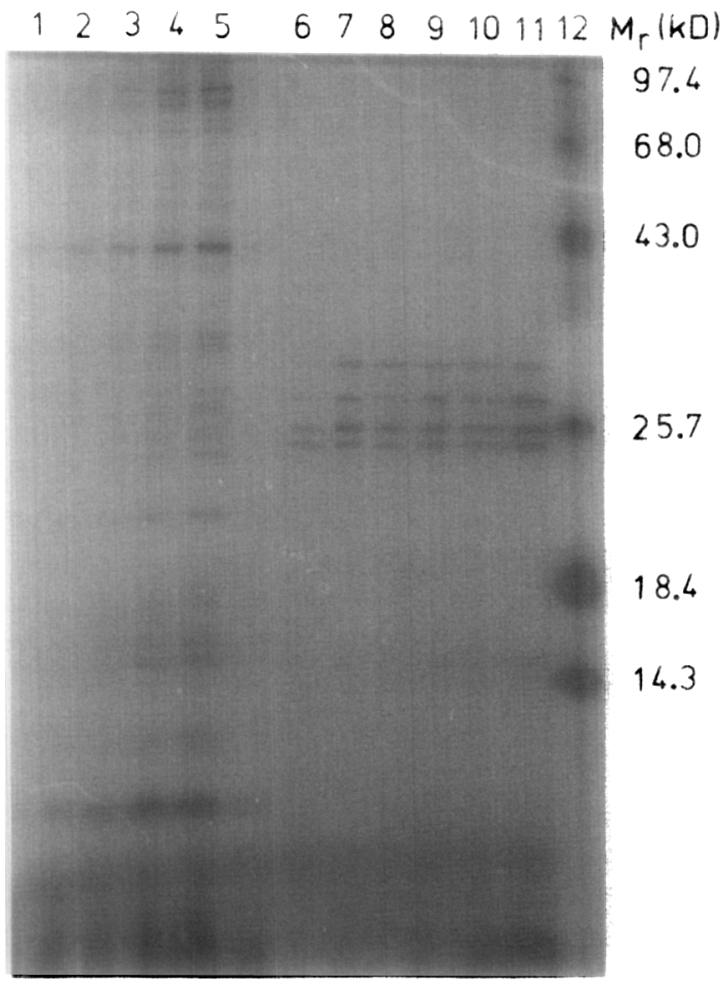

FIG. 4. Synthesis of phage-specific proteins after infection of minicells. Minicells with plasmid pMK4 and cells without plasmid were infected with phage $\mathrm{P} 1 \mathrm{Cmc} 1.100$ with a m.o.i. of 10 . After preadsorption for 20 min at $37^{\circ}$ proteins were labeled with [ ${ }^{35}$ S]methionine. Samples were taken at various times after labeling, and proteins of the lysed cells were separated by electrophoresis through a 14-20\% SDS-polyacrylamide gel. The autoradiogram shows proteins synthesized in cells without plasmid $0,10,20,30$, and 40 min after preadsorption (lanes 1-5); in cells with plasmid pMK4 without infection (lane 6); and in cells with plasmid pMK4 0, 10, 20,30, and $40 \mathrm{~min}$ after preadsorption (lanes 7-11). Marker proteins (lane 12). 
TABLE 2

Bacterial TRANSDUction ror pro ${ }^{+}$, his $^{+}$, and $\mathrm{arg}^{+}$in pMK4 Cell3

\begin{tabular}{lccc} 
& \multicolumn{2}{c}{ Transductants/ml } & \\
\cline { 2 - 3 } Marker & $\begin{array}{c}\text { AB1157 pUC13 } \\
\text { A }\end{array}$ & $\begin{array}{c}\text { AB1157 pMK4 } \\
\text { B }\end{array}$ & $\begin{array}{c}\text { \% Residual } \\
\text { transduction } \\
\text { (AVB) }\end{array}$ \\
\hline pro & $1.7 \times 10^{3}$ & $1.1 \times 10^{2}$ & 6.5 \\
his & $3.0 \times 10^{3}$ & $2.1 \times 10^{2}$ & 7.0 \\
arg & $7.1 \times 10^{3}$ & $3.8 \times 10^{2}$ & 5.3 \\
\hline
\end{tabular}

Note. The donor phage was grown in E. coli C600. The m.o.i. was about 1 and the titer of the recipient cells (AB1157) was $5 \times 10^{8} / \mathrm{ml}$.

for example, by inhibiting the cre protein (Sternberg and Hamilton, 1981). To test this, E. coli recBC with and without pMK4 was transfected with linear P1Cmc1.100 DNA using the $\mathrm{Ca}^{2+}$ method (Mandel and Higa, 1970). After plating with indicator cells, incubation was at $42^{\circ}$ to force all successfully transfected cells into the lytic cycle of phage development. The efficiency of transfection of cells carrying pMK4 (2.0 $\times 10^{-6} /$ cell) was not lower than that of cells without the plasmid $\left(0.9 \times 10^{-6} /\right.$ cell). This shows that linear P1 DNA can enter the cell (differently from normal infection) and can perfectly initiate replication in the presence of pMK 4 by the required recombinational circularization.

The above observations exclude several hypotheses on $\operatorname{sim}$ action and leave the possibility that sim prevents the successful injection of phage DNA during infection, such that the DNA does not enter the cytoplasm. We examined this possibility in two different ways. If $\mathrm{P} 1 \mathrm{DNA}$ can enter the cytoplasm after infection of $E$. coli pMK 4 cells and be maintained at least temporarily, we would expect expression of at least some phage genes. This was not observed. Within $40 \mathrm{~min}$ after infection of cells without plasmid, numerous phage-encoded proteins appeared in the cell, while in cells with pMK4 no expression of $\mathrm{P} 1$-specific genes was detected (Fig. 4). In other experiments we observed that bacterial transduction was greatly inhibited by sim. Table 2 shows that the transduction frequencies of the three markers tested $\left(\mathrm{pro}^{+}, \mathrm{his}^{+}, \mathrm{arg}^{+}\right)$were reduced by more than one order of magnitude when pMK4 was present in the recipient cell. Since the presence of the sim gene product(s) in the cell inhibited P1 infection and bacterial transduction, it is concluded that the sim system blocks the transfer of DNA from the adsorbed $\mathrm{P} 1$ phage into the cytoplasm. The phage infection was reduced by a factor of about $10^{-6}$ and the bacterial transduction by a factor of about $5 \times 10^{-2}$ (Tables 1 and 2). This could indicate a discrimination of $\operatorname{sim}$ between P1 DNA and bacterial DNA, but other explanations are also possible.

\section{Specificity of sim function}

Overexpression of the sim gene product inhibited the growth of the P1 wild type and all P1 mutants tested (P1c4.32, P1c1.100, P1 vir ${ }^{\mathrm{S}}$ ) as well as the heteroimmune phage $P 7$. Other phages tested $(\lambda, T 4, T 5, T 7$, $\phi \times 174$, and $\mathrm{Mu}$ ) had normal efficiencies of plating on cells with plasmid pMK1 (data not shown).

\section{DISCUSSION}

We have tried to find out which step of phage development is blocked by the sim function. We show that sim interferes with neither the maintenance or replication of prophage nor the vegetative replication, maturation, and release of progeny phages. Adsorption of phages to cells with plasmid pMK4 was normal. Transfection experiments demonstrated that P1 DNA can enter the cell and subsequently efficiently initiate and complete vegetative phage growth. This argues against the possibility that recombinational circularization of P1 DNA is blocked by the sim function. Phageencoded proteins were not detected in P1-infected pMK4 cells, and transduction of host cells by the $\mathrm{Cm}$ gene of $P 1$ or by chromosomal markers was greatly reduced. We conclude from these data that sim must interfere with some early step between adsorption of phage and circularization of the injected DNA. We favor the hypothesis that sim codes for a function which specifically blocks DNA injection into the cytoplasm after adsorption of phage $\mathrm{P} 1$ to the receptor site. Such a mechanism of superinfection exclusion would resemble those observed with phages T4 and P22 (Anderson and Eigner, 1971; Susskind et al., 1974). There are several similarities between the sieA system of phage P22 of Salmonella thyphimurium and the sim system of phage $\mathrm{P} 1$. The sieA gene is located in the $\mathrm{imml}$ region upstream of the genes $m n t$ and ant (Susskind et al., 1971). The ant gene of P22 codes for an antirepressor and the $m n t$ gene for a repressor of the ant gene (Susskind and Botstein, 1975). The $\mathrm{imml}$ region of phage $\mathrm{P} 1$ is organized in a manner similar to that of phage P22. The gene ant $t_{\mathrm{P}}$ is the analog of the antirepressor gene of P22 (ant $t_{P_{2}}$ ) and the P1 gene $c 4$ is analogous to the P22 gene $m n t$. The three P1 genes are located on the genetic map in the sequence sim, c4, ant (Yarmolinsky, 1987).

Apart from their corresponding locations on the genome there are also some similarities in effects of sim and sieA:

(1) Adsorption of infecting phage is not prevented in either system. 
(2) Neither sieA $A^{+}$cells nor $\operatorname{sim}^{+}$cells are killed after infection with phage.

(3) The failure to kill the cells cannot be explained by quantitative lysogenization of the cells by superinfecting phages.

(4) Thermal induction of prophages is not blocked.

(5) SieA as sim strongly reduce transduction frequencies (Ebel-Tsipis and Botstein, 1971).

(6) There is no expression of gene products by superinfecting phages.

Our results show that the immunity phenotype caused by the sim gene of bacteriophage P1 is correlated with the presence of three proteins with molecular weights of 25,24 , and $15 \mathrm{kDa}$. So far we do not know whether all three proteins are required for immunity. It appears that these proteins are transcribed from one promoter. Cells carrying the plasmid pMK4d6 still synthesize the three proteins although the coding capacity of $1300 \mathrm{bp}$ is not sufficient for all of them. Therefore we assume that one of the proteins (probably the $25-\mathrm{kDa}$ protein) is a precursor protein perhaps with a hydrophobic leader sequence at the $\mathrm{N}$-terminal end. The processed protein could be the 24-kDa protein. This interpretation is consistent with the idea that the sim protein prevents a successful injection of DNA after $\mathrm{P} 1$ adsorption and is located in the periplasmic space or is associated with the phage receptor. The DNA sequence of the sim region and isolation and sequencing of the N-terminal end of the 25- and $24-\mathrm{kDa}$ proteins will help to determine whether this hypothesis is correct.

\section{ACKNOWLEDGMENT}

We thank U. Beigel for excellent technical assistance.

\section{REFERENCES}

ANDERSON, C. W., and EIGNER, J. (1971). Breakdown and exclusion of superinfecting T-even bacteriophages in Fscherichia coli. I. Virol. 8, 869-886.

BÄCHI, B., and ARBER, W. (1977). Physical mapping of Bg/ll, BamHI, EcoRI, Hindlll and Pstl restriction tragments of bacteriophage P1 DNA. Mol. Gen. Genet. 153, 311-324.

BaumstaRk, B., and ScotT, J. R. (1987). The $c 4$ gene of phage P1. Virology 156, 197-203.

Botstein, D., Lew, K. K., Jarvik, V., and Swanson, C. A. (1975). Role of antirepressor in the bipartite control of repression and immunity by bacteriophage P22. J. Mol. Biol. 91, 439-462.

Devlin, B. H., BaumstaRk, B. R., and ScotT, J. R. (1982). Supcrimmunity: Characterization of a new gene in the immunity region of $P 1$. Virology 120, 360-375.

DreiseikelmanN, B., Velleman, M., and SCHuster, H. (1988). The $c 1$ repressor of bacteriophage $\mathrm{P} 1$ : Isolation and characterization of the repressor protein. J. Biol. Chem. 263, 1391-1397.

EBEL-TSIPIS, J., and BOTSTEIN, D. (1971). Superinfection exclusion by P22 prophage in lysogens of Salmonella thyphimurium. I. Exclusion of generalized transducing particles. Virology 45, 629-637.

Heilmann, H., ReEve, J. N., and PühleR, A. (1980). Identification of the repressor and repressor bypass (antirepressor) polypeptides of bacteriophage P1 synthesized in infected minicells. Mol. Gen. Genet. 178, 149-154.

LAEMMLI, U. K. (1970). Cleavage of structural proteins during the assembly of the head of bacteriophage T4. Nature (London) 227 , 680-685.

Levine, M., Truesdell, S., Ramakrishnan, T., and Bronson, M. (1975). Dual control of lysogeny of bacteriophage P22: An anti repressor locus and its controlling elements. J. Mol. Biol. 91, 421438.

Magazin, M., ReEve, J. N., MaYnard-Smith, S., and SYMonds, N. (1978). Bacteriophage Mu encoded polypeptides synthesized in infected minicells. FEMS Microbiol. Lett. 4, 5-9.

MANDEL, M., and HIGA, A. (1970). Calcium dependent bacteriophage DNA infection. J. Mol. Biol. 53, 159-162.

MANIATIS, T., FritSCH, E. F., and SAMBroOK, J. (1982). In "Molecular Cloning: A Laboratory Manual" p. 250. Cold Spring Harbor Laboratory, Cold Spring Harbor, NY.

REEVE, J. N. (1979). Use of Minicells for Bacteriophage Directed Polypeptide Biosynthesis. In "Methods in Enzymology" (R. Wu, Ed.), Vol. 68, pp. 493-503. Academic Press, New York.

ScoT, J. R. (1980). Immunity and repression in bacteriophages P1 and P7. Curr. Top. Microbiol. Immunol. 90, 49-65.

SCOT, J. R., WEST, B. W., and LAPING, J. L. (1978). Superinfection immunity and prophage repression in phage $P 1$. IV. The $c 1$ repressor bypass function and the role of $c 4$ repressor in immunity. Virology 85, 587-600.

SEgEV, N., and COHEN, G. (1981). Control of circularization of bacteriophage P1 DNA in Escherichia coli. Virology 114, 333-342.

Sternberg, N., and HamiLton, D. (1981). Bacteriophage $P 1$ site specific recombination. I. Recombination between loxP sites. J. Mol. Biol. 150, 467-486

SternberG, N., Hamilton, D., Austin, S., Yarmolinsky, M., and HOESS, R. (1981). Site-specific recombination and its role in the life cycle of bacteriophage P1. Cold Spring Harbor Symp. Quant. Biol. 45, 297-309.

SteRnBERG, N., and HOESS, R. (1983). The molecular genetics of bacteriophage P1. Annu. Rev. Genet. 17, 123-154.

SUSSKIND, M. M., WRIGHT, A., and BOTSTEIN, D. (1971). Superinfection exclusion by P22 prophage in lysogens of Salmonella thyphimurium. II. Genetic evidence for two exclusion systems. Virology 45, 638-652.

SUSSKIND, M. M., and Botstein, D. (1975). Mechanism of action of Salmonella phage P22 antirepressor. J. Mol. Biol. 98, 413-424.

SUSSKIND, M. M., BOTSTEIN, D., and WRIGHT, A. (1974). Superinfection exclusion by P22 prophage in lysogens of Salmonella thyphimurium. III. Failure of superinfecting DNA to enter sieA $A^{+}$lysogens. Virology 62, 350-366.

VIFIRA, J., and MFSSING, J. (1982). The pUC plasmids, and M13mp7derived system for insertion mutagenesis and sequencing with synthetic universal primers. Gene 19, 259-268.

YANISCH-PerRon, C., VIEIRA, J., and Messing, J. (1985). Improved M13 phage cloning vectors and host strains: Nucleotide sequences of the M13mp18 and pUC19 vectors. Gene 33, 103-119.

YARMOLINSKY, M. (1987). Bacteriophage P1. In "Genetic Maps, 1987" (S. J. O'Brien, Ed.), Vol. 4, pp. 38-47. Cold Spring Harbor Laboratory, Cold Spring Harbor, NY. 